\title{
A Review of Nano Fertilizers and Their Use and Functions in Soil
}

\author{
P. Selva Preetha and N. Balakrishnan* \\ Department of Soil Science and Agricultural Chemistry, Tamil Nadu Agricultural University, \\ Coimbatore - 641 003, Tamil Nadu, India \\ *Corresponding author
}

\begin{tabular}{|c|c|}
\hline \multicolumn{2}{|r|}{ A B S T R A C T } \\
\hline & \multirow{5}{*}{$\begin{array}{l}\text { With the global upsurge in population and rapid urbanization, farmers across the globe are } \\
\text { left with the daunting task of feeding more mouths every year from agricultural fields } \\
\text { which are dwindling correspondingly. Satellite images show that the Earth is rapidly } \\
\text { running out of fertile land and that food production will soon be unable to keep up with the } \\
\text { world's burgeoning population. The production level of food grains has become a subject } \\
\text { of concern as it has been showing a downward trend over the last decade. With natural } \\
\text { resources getting exhausted, it is through agriculture that we can envisage a self- } \\
\text { sustainable world. With limited availability of land and water resources, growth in } \\
\text { agriculture can be achieved only by increasing productivity through an effective use of } \\
\text { modern technology. Nanotechnology possesses the potential to augment agricultural } \\
\text { productivity through genetic improvement of plants and animals along with cellular level } \\
\text { delivery of genes and drug molecules to specific sites in plants and animals. The potential } \\
\text { is increasing with suitable techniques and sensors being identified for precision } \\
\text { agriculture, natural resource management, efficient delivery systems for agrochemicals } \\
\text { such as fertilizers and pesticides, food processing, packaging and other areas like } \\
\text { monitoring agricultural and food system security. Here we review the contribution of } \\
\text { nanotechnology technique on development of nano fertilizer and its uses and function in } \\
\text { soil. }\end{array}$} \\
\hline Keywords & \\
\hline Article Info & \\
\hline $\begin{array}{l}\text { Accepted: } \\
\text { 23 October } 2017 \\
\text { Available Online: } \\
\text { 10 December } 2017\end{array}$ & \\
\hline & \\
\hline
\end{tabular}

\section{Introduction}

Nanotechnology, focusing on special properties of materials emerging from nanometric size has the potential to revolutionize in the food sector, biomedicine, environmental engineering, safety and security, water resources, energy conversion, and numerous other areas (Baruah et al., 2008). Nanotechnology applications in agriculture are gradually transforming the theoretical possibilities into the practical applications. Novel tools are being designed which can operate at nanometric levels to boost research in molecular and cellular biology. Nanotechnology possesses the potential to augment agricultural productivity through genetic improvement of plants and animals (Kuzma, 2006; Scott 2007) along with cellular level delivery of genes and drug molecules to specific sites in plants and animals (Maysinger, 2007). The potential is increasing with suitable techniques and sensors being identified for precision agriculture, natural resource management, early detection of pathogens and contaminants in food products, efficient delivery systems for agrochemicals such as fertilizers and 
pesticides, improved systems integration for food processing, packaging and other areas like monitoring agricultural and food system security (Moraru et al., 2003; Chau et al., 2007; Subramanian and Rahale, 2009). With increased innovations using nanotechnology in the agricultural sector, it can be envisaged to become the major economic driving force and benefit consumers and farmers with no detrimental effect on the ecosystem. There is an emerging area of interest in the utilization of nanoporous zeolites in farming over the years because of current public concern about the adverse effects of chemical fertilizers on the agro-ecosystem.

\section{Nanotechnology application}

Nanotechnology is the manipulation or selfassembly of individual atoms, molecules, or molecular clusters into structures to create materials and devices with new or vastly different properties. The emergence of nanotechnology and the development of new nanodevices and nanomaterials open up potential novel applications in agriculture. Nanotechnology is defined as "the understanding and control of matter at dimensions of roughly $1-100 \mathrm{~nm}$, where unique properties make novel applications possible". By manipulating molecules on the scale of billionths-of-a-meter, scientists have created materials that exhibit "almost magical feats of conductivity, reactivity, and optical sensitivity, among others". This also has the potential to drive an economic revolution. Retailers already sell over 300 products that incorporate nanotechnology (Science Policy Council, 2007), and according to one estimate, nanotechnology will be a trilliondollar-a-year industry by 2015 (Roco, 2003). It is a highly promising technology that spans many areas of science and technological applications. Rapid advancements in nanoscience and nanotechnologies in recent years have opened up new horizons for many industrial and consumer sectors that have been regarded as the hotbed of a new industrial revolution including agriculture and allied sectors. Kuzma and Verhage (2006) reported that among the recent advancements in science, nanotechnology is fast emerging as the new science and technology platform for the next generation of development and transformation of agri-food systems as well as for improving the conditions of the poor people.

Nanoscale materials and devices can be fabricated using either "bottom-up" or "topdown" fabrication approaches. In bottom-up methods, nanomaterials or structures are fabricated from buildup of atoms or molecules in a controlled manner that is regulated by thermodynamic means such as self-assembly (Ferrari, 2005). Alternatively, advances in micro technologies can be used to fabricate nanoscale structures and devices. These techniques are collectively referred to as top-down nanofabrication technologies, include photolithography, nanomolding, dippen lithography and nanofluidics (Peppas, 2004; Sahoo and Labhasetwar (2003)). Abdul-Kalam (2007) suggested that nanotechnology has potential to bring the next revolutionary breakthrough in agriculturalbased natural resource management. It has ushered as a new interdisciplinary venturefield by converging science and engineering into agriculture and food systems.

\section{Nanotechnology applications in agriculture}

Nanotechnology has a wide applications in medicine (Zhou et al., 2004), environment (Shi et al., 2007), energy (Das et al., 2007), information and communication (Hillie, 2007), heavy industry (Lo et al., 2010) and consumer goods (Schneider, 2010). Despite the fact that nanotechnology is extensively exploited in health and medical sciences, the use of nanotechnology in agriculture and food 
system is just emerging and expected to grow alarmingly. Globally, agrifood sector has been identified as a potential industry to make significant investments. Currently, over 300 nanofood products are available in the international markets. According to a recent study by Helmuth Kaiser Consultancy (Germany), the nanofood market was expected to surge from USD 2.6 billion in 2004 to USD 20 billion by 2010 . The report suggested that with more than $50 \%$ of the world population, the largest market for nanofood in 2010 will be Asia, led by China.

Nanotechnology has the potential to revolutionize the agricultural and food industry with new tools for the molecular treatment of diseases, rapid disease detection, enhancing the ability of plants to absorb nutrients etc. Smart sensors and smart delivery systems will help the agricultural industry combat viruses and other crop pathogens. In the near future nanostructured catalysts will be available which will increase the efficiency of pesticides and herbicides, allowing lower doses to be used. Nanotechnology will also protect the environment indirectly through the use of alternative (renewable) energy supplies, and filters or catalysts to reduce pollution and clean-up the existing pollutants.

Potential applications of nanotechnology in developing countries identified agricultural productivity enhancement as the second most critical area of application for attaining the millennium development goals while energy conversion and storage was ranked first and water treatment as the third areas needing focus (Buentello et al., 2005). Ultimately, precision farming, with the help of smart sensors, will allow enhanced productivity in agriculture by providing accurate information, thus helping farmers to make better decisions. In the future, nanoscale devices with novel properties could be used to make agricultural systems "smart". For example, devices could be used to identify plant health issues before these become visible to the farmer. Such devices may be capable of responding to different situations by taking appropriate remedial action.

\section{Nanofertilizer}

Nanofertilizer technology is very innovative and scanty reported literatures are available in the scientific journals. Nutrient use efficiencies of conventional fertilizers hardly exceed $30-35 \%, 18-20 \%$ and $35-40 \%$ for $\mathrm{N}$, $\mathrm{P}$ and $\mathrm{K}$ respectively. The data remain constant for the past several decade and research efforts did not yield fruitful results. Nano-fertilizers are nutrient carriers that are being developed using substrates with nanodimensions of $1-100 \mathrm{~nm}$. Nano particles have extensive surface area and capable of holding abundance of nutrients and release it slowly and steadily such that it facilitates uptake of nutrients matching the crop requirement without any associated illeffects of customized fertilizer inputs.

The current growing awareness of the phenomenon and availability of inexpensive natural zeolites in the world has aroused considerable commercial interest on developing zeolite based nano fertilizer. Chuprova et al., (2004) found the beneficial effects of zeolite fertilizers on mobile humus substances of Chernozem and on biological productivity of maize. In another study, a patented nano-composite consists of $\mathrm{N}, \mathrm{P}, \mathrm{K}$ and micronutrients and mannose and amino acids have been shown to increase the uptake and utilization of nutrients by grain crops (Jinghua, 2004). Bhattacharya (2004) reported that the balanced application of NPK along with S, Zn, B and Mo will be an effective solution for higher grain yield of pulses in red and lateritic soils. Adequate NPK fertilization increased green and blackgram yields by $13 \%$ 
and $38 \%$ over the control. Liu et al., (2006) have shown that the organic material (polystyrene) intercalated in the layers of kaolinite clay form a cementing of nano and subnano-composites which are capable of regulating the release of nutrients from the fertilizer capsule. Thus nano-particles could be used in the membrane control release of nutrients. Subramanian et al., (2008) reported that nano-fertilizers and nanocomposites can be used to control the release of nutrients from the fertilizer granules so as to improve the nutrient use efficiency while preventing the nutrient ions from either getting fixed or lost to the environment.

Recently, SharmilaRahale (2011) has monitored the nutrient release pattern of nanofertiliser formulations carrying nitrogen. The data have shown the nano-clay based fertilizer formulations (zeolite and montmorillonite with a dimension of 30-40 $\mathrm{nm}$ ) are capable of releasing the nitrogen for a longer period of time (> $1000 \mathrm{hrs})$ than conventional fertilizers $(<500$ hrs $)$. Nanotechnology can be exploited to improve the efficiencies of native and added sources of nutrients. Nanofertilizer technology improves the fertilizer use efficiency of crops. There is an increasing interest in the utilization of nanoporous zeolites in farming over the years because of current public concern about the adverse effects of chemical fertilizers on the agro-ecosystem (Ramesh et al., 2010).These reports and patented products strongly suggest that there is a vast scope for the formulation of nano- fertilizers (Liu et al., 2006; Subramanian et al., 2008; DeRosa, 2010). Nanofertilizer may be a strategy to improve the nutrient use efficiency of crops and crop productivity.

\section{Characteristics of zeolites}

Zeolites, a naturally occurring mineral group consisting of about 50 mineral types, draw attention as a good growing medium substrate for a long period due to its good physical and chemical characteristics (Markovich et al., 1995). They have a rigid three-dimensional crystal structure with voids and channels of molecular size and high cation exchange capacity (CEC) arising from substitution of $\mathrm{Al}$ for $\mathrm{Si}$ in the silicon oxide tetrahedral units that constitute the mineral structure (Ayan, 2001 and 2002a; Pickering et al., 2002).

Clinoptilolite zeolites unique crystalline latticework structure and channels adsorbs water through a highly porous molecular matrix with an immense surface area, while its negative charge acts as a magnet attracting, holding, and exchanging positively charged particles (cations) (Desborough, 1996).

The characteristic of zeolite was given by Junrungreang et al., (2002) that zeolite was considered to be representative in term of its composition CEC (133.92 cmol $\left.\left(\mathrm{p}^{+}\right) \mathrm{kg}^{-1}\right), \mathrm{K}$ $\left(19.83 \mathrm{cmol} \mathrm{kg}^{-1}\right), \mathrm{Ca}\left(161.96 \mathrm{cmol} \mathrm{kg}^{-1}\right), \mathrm{Mg}$ $\left(16.40 \mathrm{cmol} \mathrm{kg}^{-1}\right), \mathrm{Na}\left(13.97 \mathrm{cmol} \mathrm{kg}^{-1}\right), \mathrm{P}_{2} \mathrm{O}_{5}$ (426 mg kg ${ }^{-1}$ ), $\mathrm{pH}(6.4), \mathrm{SiO}_{2}(71 \%), \mathrm{Al}_{2} \mathrm{O}_{3}$ (11\%), $\mathrm{Fe}_{2} \mathrm{O}_{3}$ (3.13\%), $\mathrm{Na}_{2} \mathrm{O}$ (1.09\%), $\mathrm{MgO}$ $(0.61 \%), \mathrm{K}_{2} \mathrm{O}(2.54 \%)$, and $\mathrm{CaO}(2.56 \%)$, respectively.

The nano-zeolite has hexagonal symmetry (Baerlocher et al., 2001) with two dimensional pores of about $0.71 \mathrm{~nm}$ aperture leading to cavities of about $0.48 \times 124 \times 1.07$ $\mathrm{nm}$ and the $\mathrm{Si} / \mathrm{Al}$ ratio is typically 3.0 (Bruhwiler, 2005). The nano-zeolite crystal consists of cages linked by double six membered rings, forming columns in the $\mathrm{C}$ direction. Connection of these columns give rise to 12-membered rings with a free diameter varying from $0.71 \mathrm{~nm}$ to $1.26 \mathrm{~nm}$ (Agger, 2003). The literature review suggests that zeolite is natural mineral having extensive surface area and can hold wide range of $+v e$ and $-v e$ nutrient ions after suitable partial modification. 


\section{Essential Nutrients}

\section{Macronutrients - Nitrogen nanofertiliser}

Nitrogen is an important component of many important structural, genetic and metabolic compounds in plant cells. It is a major component of chlorophyll, the compound by which plants use sunlight energy to produce sugars from water and carbon dioxide (i.e. photosynthesis). It is also a major component of amino acids, the building blocks of proteins. Some proteins act as structural units in plant cells while others act as enzymes, making possible many of the biochemical reactions on which life is based. Nitrogen is a component of energy-transfer compounds, such as ATP (adenosine triphosphate) which allows cells to conserve and use the energy released in metabolism. Finally, nitrogen is a significant component of nucleic acids such as DNA, the genetic material that allows cells (and eventually whole plants) to grow and reproduce. Since nitrogen exists in three general forms - organic nitrogen compounds, ammonium $\left(\mathrm{NH}_{4}{ }^{+}\right)$ions, and nitrate $\left(\mathrm{NO}_{3}{ }^{-}\right)$ ions which is available for plant. Most of the nitrogen is not available for plant completely. This is because negatively charged nitrate normally does not have higher affinity for soil particle surfaces and thus does not readily sorb on soil.

To overcome the problems associated with the nitrogen leaching during fertilization, different approaches such as polyolefin resincoated urea, neem coated urea, sulphur coated urea were taken to control the $\mathrm{N}$ release. However, slow-releasing fertilizers are often expensive and the release of $\mathrm{N}$ is slow at the time of high $\mathrm{N}$. $\mathrm{N}$ loss can also be reduced using cation exchanger as additives in fertilizer to control $\mathrm{NH}_{4}{ }^{+}$release. The retention and timely release of needed nutrients by zeolite improves overall crop yield.
Clinoptilolite zeolite (CZ), a porous mineral with high cation exchange capacity (CEC, up to $\left.300 \mathrm{c} \mathrm{mol}\left(\mathrm{p}^{+}\right) \mathrm{kg}^{-1}\right)$ and with great affinity for $\mathrm{NH}_{4}{ }^{+}$(Ming and Mumpton, 1989), has been used to reduce $\mathrm{NH}_{3}$ emission from farm manure (Amon et al., 1997), and to eliminate $\mathrm{NH}_{3}$ toxicity to plants (Gupta et al., 1997). Amendment of clinoptilolite zeolite (CZ) to sandy soil has been reported to lower $\mathrm{NO}_{3}{ }^{-}$ and $\mathrm{NH}_{4}{ }^{+}$concentrations in the leachate and to increase moisture retention in the soil due to increased soil surface area and CEC (Huang and Petrovic, 1994). Urea nitrogen has been the most used $\mathrm{N}$-source due to lower cost per unit of N. But $\mathrm{N}$ use efficiency of urea may be reduced because of losses from agricultural system by volatilization of ammonia to atmosphere. This is one of the main factors responsible for the low efficiency of urea, and may reach extreme values, close to $80 \%$ of $\mathrm{N}$ applied. Ammonium retained by $\mathrm{CZ}$ is generally subjected to slow release through cation exchange and nitrification in soil (Kithome et al., 1998).

Clinoptilolite zeolite has been used to reduce $\mathrm{NH}_{3}$ emission from farm manures (Amon $e t$ al., 1997) and as $\mathrm{NH}_{4}{ }^{+}$- loaded exchange fertilizer (Perrin et al., 1998a, b) because of its high CEC. Application of $\left(\mathrm{NH}_{4}\right)_{2} \mathrm{SO}_{4}$ loaded into $\mathrm{CZ}$ was observed to minimize $\mathrm{N}$ leaching and to increase $\mathrm{N}$ utilization by crops in sandy soils compared with $\left(\mathrm{NH}_{4}\right)_{2} \mathrm{SO}_{4}$ alone (Perrin et al., 1998a, b). Perrin et al., (1998) stated that clinoptilolite not only improves nitrogen fertilization efficiencies, it also reduces nitrate leaching by inhibiting the nitrification of ammonium to nitrate. Lefcourt and Meisinger (2001) reported that zeolite has the potential for reducing ammonia volatilization by sequestering ammonium-N on exchange cites. An addition of $6.25 \%$ zeolite resulted in a $50 \%$ reduction in ammonia volatilization. An additional potential advantage is that zeolite bound ammonium is a good slow-release $\mathrm{N}$ source 
for plants. Unlike the commonly used fertilizers, the plant-growth material dramatically reduces loss of nutrients to groundwater and the environment. The Nurea losses can also be reduced using zeolites as additives in the fertilizers to control the retention and release of $\mathrm{NH}_{4}{ }^{+}$. There are reports in the literature showing that the addition of zeolite to the source of $\mathrm{N}$ can improve the nitrogen use efficiency (Ming and Mumpton 1989; McGilloway et al., 2003; Gruener et al., 2003; Rehakova et al., 2004). Li (2003) demonstrated the feasibility of using surfactant-modified zeolite (SMZ) using hexadecyltrimethyl ammonium as fertilizer carrier to control nitrate release, and concluded that SMZ is a good sorbent for nitrate, whereas slow release of nitrate is achievable.

Bhardwaj and Tomar (2011) conducted laboratory batch experiments to investigate the sorption of nitrate from aqueous solutions using hydrothermally synthesized and surface modified zeolite nano particles. The ability of surface modification with hexadecyltrimethyl ammonium (HDTMA) and Dioctadecyldimethyl ammonium greatly enhance the sorption and slow release of nitrate. Latifah et al., (2011) confirmed that mixing urea with zeolite and sago waste water had great advantage over urea alone as the mixture encouraged the formation of ammonium and available nitrate ions over ammonia. The mixture also improved retention of exchangeable ammonium and available nitrate within the soil. Recently, Sharmila Rahale (2011) had monitored the nutrient release pattern of nanofertiliser formulations carrying nitrogen.

They had shown that nano-fertilizer released nutrients upto $1200 \mathrm{hrs}$ while conventional fertilizer could support only for 300- $350 \mathrm{hrs}$. The data had clearly demonstrated that zeolite as nano- fertilizer could be an ideal strategy to promote $\mathrm{N}$ use efficiency.

\section{Phosphorus nano-fertilizer}

Phosphorus is an essential nutrient both as a part of several key plant structure compounds and as a catalysis in the conversion of numerous key biochemical reactions in plants. Phosphorus is the most important nutrient for its function as an energy transfer and storage in plants.

Adenosine di- and triphosphates (ADP and ATP) are the most important forms of phosphates that are involved in the energy transfer. It is also an important structural component of phosphor- proteins, phospholipids, sugar phosphates, coenzymes, nucleic acids, and metabolic substrates in plants. Supply of $\mathrm{P}$ at the early stage of crop is essential for its development of reproductive structures. Some specific growth factors that have been associated with phosphorus are: stimulated root development, increased stalk and stem strength, improved flower formation and seed production, more uniform and earlier crop maturity, increased $\mathrm{N}$-fixing capacity of legumes, improvement in crop quality and increased resistance to plant diseases.

Allen et al., (1996) conducted studies to examine the solubility and cation-exchange in mixtures of rock phosphate and $\mathrm{NH}_{4}{ }^{+}$and $\mathrm{K}$ saturated clinoptilolite revealed that mixtures of zeolite and phosphate rock had the potential to provide slow-release fertilization of plants in synthetic soils by dissolution and ion-exchange reactions. Malhi et al., (2002) reported that the zeolites (clinoptilolite), when saturated with mono-valent nutrient cations, such as $\mathrm{NH}_{4}^{+}$and $\mathrm{K}^{+}$have been reported to increase the solubility of phosphate rock (PR). The efficiency of fertilizer $\mathrm{P}$ use by crops ranged from 18 to $20 \%$ in the year that it is applied. The remaining 78 to $80 \%$ becomes part of the soil $\mathrm{P}$ pool which is released to the crop over the following months and years. 
Bansiwal et al., (2006) demonstrated that the release of $\mathrm{P}$ from fertilizer-loaded unmodified zeolite, surface modified zeolite (SMZ) and from solid $\mathrm{KH}_{2} \mathrm{PO}_{4}$ were performed using the constant flow percolation reactor. The results showed that the $\mathrm{P}$ supply from fertilizerloaded SMZ was available even after $1080 \mathrm{~h}$ of continuous percolation, whereas $\mathrm{P}$ from $\mathrm{KH}_{2} \mathrm{PO}_{4}$ was exhausted within $264 \mathrm{~h}$. The results indicated that $\mathrm{SMZ}$ is a good sorbent for $\mathrm{PO}_{4}{ }^{3-}$, and a slow release of $\mathrm{P}$ is achievable. These properties suggested that SMZ has a great potential as the fertilizer carrier for slow release of P. Eberl (2008) reported that phosphate $\left(\mathrm{H}_{2} \mathrm{PO}_{4}\right)$ can be released to plants from phosphate rock ( $\mathrm{P}$ rock) composed largely of the calcium phosphate mineral apatite by mixing the rock with zeolite having an exchange ion such as ammonium. The approximate reaction in soil solution is as follows:

$(\mathrm{P}$-rock $)+\left(\mathrm{NH}_{4}-\right.$ zeolite $)=(\mathrm{Ca}$ zeolite $)+$ $\left(\mathrm{NH}_{4}\right)+\left(\mathrm{H}_{2} \mathrm{PO}_{4}^{-}\right)$

The zeolite takes $\mathrm{Ca}^{2+}$ from the phosphate rock, thereby releasing both phosphate and ammonium ions. Unlike the leaching of very soluble phosphate established equilibrium, the fertilizers (for example, super phosphate), the controlled-release phosphate is released of a specific chemical reaction in soil. As phosphate is taken up by plants or by soil fixation, the chemical reaction releases more phosphate and ammonium in the attempt to reestablish equilibrium. The rate of phosphate release is controlled by varying the ratio of $\mathrm{P}$ rock to zeolite. Phosphorus is also released from the rock by the lowering of soil $\mathrm{pH}$ as ammonium ions are converted to nitrate. Andrews and Shaw (2010) reported that zeoponic is a plant demand driven nutrient delivery system and from this phosphate $\left(\mathrm{PO}_{4}{ }^{3-}\right)$ and other nutrients released by controlled dissolution of synthetic apatite. N, $\mathrm{P}$ and $\mathrm{K}$ were delivered when plant needs them from zeoponics. Basically, the process is a combination of dissolution and ion exchange reactions. The absorption of nutrients from the soil solution by plant roots drives the dissolution and ion exchange reactions, pulling away nutrients as needed. The zeolite is then "recharged" by the addition of more dissolved nutrients. In effect, zeoponic systems increase nutrient retention, reduce environmental nutrient losses and reduce fertilizer requirements by establishing a replenishable and balanced nutrient supply in the plant root zone.

SharmilaRahale (2011) studied the $\mathrm{PO}_{4}{ }^{-}$ release pattern of surface modified using various nanoclays and zeolite in a percolation reactor. Nano- formulations have been shown to release phosphate for an extended period of 40- 50 days and the conventional fertilizer let out nutrients only upto 10- 12 days. The review of literature suggests that surface modified zeolite could be potential strategy to promote $\mathrm{P}$ use efficiency which hardly exceed 18- $20 \%$ in conventional system.

\section{Potassium nanofertilizer}

Potassium is vital to many plant processes. While potassium is not a constituent of any plant structures or compounds, it plays a part in many important regulatory roles in the plant. It is essential in nearly all processes needed to sustain plant growth and reproduction. Potassium plays a vital role in photosynthesis, translocation of photosynthates, protein synthesis, control of ionic balance, regulation of plant stomata and water use, activation of plant enzymes and many other processes. It is known to activate at least sixty enzymes involved in plant growth. Plants deficient in potassium are less resistant to drought, excess water, high and low temperatures. They are also less resistant to pests, diseases and nematode attacks. Potassium is also known as the quality 
nutrient because of its important effects on quality factors such as size, shape, color, taste, shelf life, fiber quality and other quality measurements.

Some natural zeolites contain considerable amounts of exchangeable $\mathrm{K}^{+}$that can enhance plant growth in potting media. For example, Hershey et al., (1980) provided data on the slow release effect of $\mathrm{K}$ from $\mathrm{K}$-zeolite. Mazur et al., (1986) stated that the application of chemical fertilizer at the rate $625 \mathrm{~kg}$ ha ${ }^{1}$ mixed with zeolite $125 \mathrm{~kg} \mathrm{ha}^{-1}$ indicated the largest amount of potassium in the soil because zeolite had potential to adsorb potassium from chemical fertilizer and reduce it from leakage. Natural zeolites are highly selective for $\mathrm{K}^{+}$rather than for sodium or divalent cations, such as calcium and magnesium, because of the location and density of the negative charge in the structure and dimensions of the interior channels (Ming and Mumpton, 1989). Treacy and Higgins (2001) suggested that among all, potassium is the only element with the highest ionexchange capacity of $216 \mathrm{c}$ mol $\left(\mathrm{p}^{+}\right) \mathrm{Kg}^{-1}$ (Dakovic et al., (2007) and consequently, it is very easily released from the crystal zeolite structure into the soil solution, eventually increasing its total content in the soil. Zhou and Huang (2007) reported that slow and steady release of $\mathrm{K}$ from nano-zeolite and gave the reason that it may be due to the ion exchangeability of the zeolites with selected nutrient cations, zeolites can become an excellent plant growth medium for supplying plant roots with additional vital nutrient cations and anions. Guo et al., (2008) suggested that the zeolite can be "recharged" by the addition of more dissolved nutrients. Their selectivity of ion exchange on zeolite was determined in an order of $\mathrm{K}^{+}>\mathrm{NH}_{4}{ }^{+}>$ $\mathrm{Na}^{+}>\mathrm{Ca}^{2+}>\mathrm{Mg}^{2+}$.

Rezaei et al., (2009) reported that potassium sorbed on zeolite increases with the increase in equilibrium $\mathrm{K}$ concentration. Beitollah et al., (2009) suggested that the zeolites dominated by exchangeable $\mathrm{K}$ may be wellsuited for plant growth applications. Li et al., (2010) in their study used potassium $\left(\mathrm{K}^{+}\right)$loaded zeolite (K-Z) as a slow-release fertilizer and investigated the growth characteristics of hot pepper as well as the changes in the nitrogen and potassium contents of the evaluated soil. SharmilaRahale (2011) conducted experiment on slow release of $\mathrm{K}$ fertilizer and examined their efficiency. Despite the fact that potassium fixation in soil and dynamic equilibrium collectively sustain the availability of potassium in soil, nanotechnology can further improve the availability and regulated release of nutrients.

\section{Secondary nutrients nano-fertilizer}

Sulphur (S), calcium (Ca) and magnesium $(\mathrm{Mg})$ are secondary nutrients required in relatively large amounts for good crop growth. $\mathrm{S}$ and $\mathrm{Mg}$ are needed by plants in about the same quantities as $\mathrm{P}$, whereas for many plant species, $\mathrm{Ca}$ requirement is greater than that for P. Sulphur reactions in soil are very similar to $\mathrm{N}$ reaction, which are dominated by organic or microbial fractions in the soil. In contrast, $\mathrm{Ca}^{2+}$ and $\mathrm{Mg}^{2+}$ are associated with the soil clay fraction and behave similarly to $\mathrm{K}^{+}$. Supapron et al., (2007) reported that zeolite showed slow release fertilizer for calcium and magnesium. They suggested that, zeolite improved calcium and magnesium in soil. Fansuri et al., (2008) reported that zeolite is able to freely exchange nutrient ions such as calcium and magnesium.

Li and Zhang (2010) studied the feasibility of using surfactant-modified zeolite (SMZ) as fertilizer additives to control sulfate release, was tested in batch and column leaching experiments which indicated that SMZ could be a good carrier for sulfate. Thus, leaching of 
sulfate can be greatly reduced and slow release of sulfate can be achieved if SMZ is used as fertilizer additives. Secondary nutrients are less studied as the extent of deficiencies is very meager or found in isolated products.

\section{Micronutrients nano-fertilizer}

Micronutrients are those elements that are essential for plant growth, but are required in much smaller amounts than those of $\mathrm{N}, \mathrm{P}$ and $\mathrm{K}$. The micronutrients are boron (B), copper $(\mathrm{Cu})$, iron $(\mathrm{Fe})$, manganese $(\mathrm{Mn})$, molybdenum (Mo), zinc ( $\mathrm{Zn})$ and chloride $(\mathrm{Cl})$. Eventhough micronutrients are required in minute quantities, they are essential for healthy plant growth and profitable crop production. Micronutrient deficiency is widespread in many Asian countries due to the calcareous nature of soils, high $\mathrm{pH}$, low organic matter, salt stress, continuous drought, high bicarbonate content in irrigation water and imbalanced application of NPK fertilizers. Some of the adverse effects of micronutrient deficiency-induced stress in plants include low crop yield and quality, imperfect plant morphological structure (such as fewer xylem vessels of small size), widespread infestation of various diseases and pests, low activation of phytosiderophores, and lower fertilizer use efficiency (Malakouti, 2008). Sheta et al., (2003) undertaken research to characterize the ability of five natural zeolites and bentonite minerals to adsorb and release zinc and iron. The potential for sorption of these ions were evaluated by applying the Langmuir and Freundlich equations. The results suggest that natural zeolites, particularly chabazite and bentonite minerals, have a high potential for $\mathrm{Zn}$ and Fe sorption with a high capacity for slow release fertilizers.

Broos et al., (2007) reported that slow release of $\mathrm{Zn}$ is attributed to the sparingly solubility of minerals and sequestration effect of exchange, thereby releasing trace nutrients to zeolite exchange sites where they are more readily available for uptake by plants. Schmidt and Szakal (2007) were carried out experiments on foliar treatments with ionexchanged zeolite on winter wheat for three years. As a result of zinc zeolite the increase of raw protein was more favourable than that of copper-zeolite treatment. Eberl (2008) reported that zeolite in soil can aid in the release of some trace nutrients and in their uptake in plants. The release of cationic micronutrients has been enhanced by the presence of zeolite in neutral soil. The concentration of $\mathrm{Cu}$ and $\mathrm{Mn}$ in Sudangrass (in $\mathrm{mg} / \mathrm{kg}$ ) was significantly related to the zeolite/P-rock in experimental systems that used two different $\mathrm{NH}_{4}$ saturated zeolites, two different soils and two different forms of Prock. Lin and Xing (2008) reported that zinc oxide nanoparticles were shown to enter the root tissue of ryegrass and improved the germination. Melendi et al., (2008) conducted an elegant experiment and showed a visualization of carbon coated nanotubes in plant cells using pumpkin plants as the model crop. This is one of the classic studies that can be used as a guiding tool to develop smart nutrient delivery system for plants. Pandey et al., (2010) reported that Zinc rich ZnO NPs increased the level of IAA in roots (sprouts), which in turn indicate the increase in the growth rate of plants as zinc is an essential nutrients for plants.

Boron is an essential micronutrient for plants, but can be toxic to organisms when accumulated in high concentrations. The adsorption of boron by clays, soils and other minerals has been extensively studied by many investigators (Sabarudin et al., (2005); Ferreira (2006); Turek et al., (2007); Cengeloglu et al., (2007); Bouguerra et al., (2008); Bryjak (2008); Ozturk (2008); Kose and Ozturk (2008); Kavak (2009)). 
Molybdenum is an essential component of plant enzyme nitrate reductase. Additionally, Mo is important element in nitrogenase in Nitrogen fixing bacteria essential for legume crops. Rana and Viswanathan (1998) studied Mo incorporation in MCM-41 type zeolite and IR, FT-Raman and UV-VIS DR spectroscopic analyses gave the evidences for the incorporation of Mo in the framework of MCM-41.

\section{Nano-composites}

Nanocomposites are expected to play an important role in developing new materials exhibiting unusual properties. Barbarick and others (1990) demonstrated that mixing $\mathrm{NH}_{4}$ saturated clinoptilolite with phosphate rock provided simultaneous slow-release of both $\mathrm{P}$ and N. Allen (1991) reported that N, P, K and $\mathrm{Ca}$ were slowly released from mixtures of natural phosphate rocks and $\mathrm{NH}^{4+}$ and $\mathrm{K}$ saturated clinoptilolite. Desborough (1996) concluded that CRR (clinoptilolite-rich rocks) showed potential for increasing the cationexchange capability of the soil by temporarily extracting $\mathrm{NH}_{4}{ }^{+}$when highly soluble $\mathrm{NH}_{4}{ }^{+}$ rich fertilizers are applied to crop fields. Dwairi (1998) verified that, zeolite when mixed with nitrogen, phosphorus and potassium compounds, it enhanced the action of such compounds as slow release fertilizers, both in horticultural and extensive crops. Ming and Allen (2001) summarized about the increasing fertilizer use efficiency by adding natural zeolites to soluble $\mathrm{N}$-fertilizer such as ammonium nitrate and urea as well as $\mathrm{K}$ fertilizers.

Nanocomposite films consisting of inorganic nanolayers of layered silicate, such as montmorillonite (MMT) clay and organic polymers, have recently evoked intense research interest in the material and polymer science areas (Alexandre et al., (2000); Sinha et al., (2003); Sinha et al., (2005)).
Bagdasarov et al., (2004) reported that zeolite is an excellent carrier, stabilizer and regulator of mineral fertilizers, themselves being a source of certain nutrients. Polat et al., (2004) suggested that zeolite is used as carrier of $\mathrm{N}$ and $\mathrm{K}$ fertilizers, they increase their efficacy by decreasing application rates for equal yields to be achieved.

Zhang et al., (2006) reported that results of measurements on nutrients of wheat plant showed that in treatments with the five kinds of bulk blended slow-release fertilizers, the contents of NPK absorbed by wheat in shooting period were higher than that of chemical fertilizer of equal amount of NPK, which was consistent with the rule of nutrients demanded by wheat. Liu et al., (2006) studied the nitrogen slow release behaviour of the super absorbent nitrogen fertilizer (SSNF) in water and water retention capacity of the soil with SSNF. They reported that the surface cross linked product not only had good slow release property but also excellent soil moisture preservation capacity, which could effectively improve the utilization of fertilizer and water resources simultaneously. They also obtained that the SSNF could find an application in agriculture and horticulture, especially in drought prone areas where the availability of water is insufficient.

Qiang et al., (2008) reported that wheat grain yield and protein contents were slightly improved and soluble sugar content decreased by slow/controlled release fertilizer coated and felted by nano-materials compared with NPK chemical fertilizer. It was effective to use slow/controlled release fertilizer coated by nano-materials to improve wheat yield and quality. Composites of nanomaterials and conventional materials by embedding nanotechnology in materials, researchers create new materials with enhanced physical or chemical properties. 


\section{Nano-composites on crop growth}

Nanotechnology offers an important role in improving the existing crop management techniques. Hence nanoparticulate formulations have great potential as novel tool for crop growth. Zeolite is one of the key factors which can be effectively used for enhancing the nutrient uptake thus crop growth. Flanigen and Mumpton, (1981) and Mumpton (1981) reported that the zeolites added to fertilizers help to retain nutrients and, therefore, improving the long term soil quality by enhancing its absorption ability. It concerns the most important plant nutrients such as nitrogen $(\mathrm{N})$ and potassium $(\mathrm{K})$, and also calcium, magnesium and microelements. Zeolite can retain these nutrients in the root zone to be used by plants when required. Consequently this leads to the more efficient use of $\mathrm{N}$ and $\mathrm{K}$ fertilizers by reducing their rates for the same yield, by prolonging their activity or finally by producing higher yields. Large losses of fertilizers which move out of the root zone (leaching) often happen in sandy soils, which lose their capability to retain high nutrient levels.

Burriesci et al., (1984) reported that zeolite combined with normal fertilizer greatly enhanced growth and yield of peach and grape trees. Valente et al., (1986) reported that the zeolite incorporated with chemical fertilizer gave positive effect for tomato growth. Pessarakli (1994) reported that usually the higher $\mathrm{Na}+$ content in saline soil disturbs the nutritional balance and upsets the osmotic regulations of plant tissues. Zeolite provides an alternative $\mathrm{Ca}_{2}{ }^{+}$cation to the soilplant system reducing the ratio of $\mathrm{Na}^{+} / \mathrm{Ca}^{2+}$. The provision of $\mathrm{Ca}_{2}{ }^{+}$from zeolite in the root media would prevent an accumulation of toxic $\mathrm{Na}+$ ion in plants.

Song and Fujiyama (1996) described the ameliorative effects of Ca-type zeolite on rice and tomato growth to decreases in $\mathrm{Na}^{+}$ concentration in shoots as well as $\mathrm{Na}^{+} / \mathrm{Ca}^{2+}$ and $\mathrm{Na}^{+} / \mathrm{K}^{+}$ratios of shoots and roots. Mumpton (1999) reported that the zeolites are mixed with chemical fertilizers, they help to retain nutrients in root zone and, hence, improving the long term soil quality by enhancing nutrient absorption. Steinberg et al., (2000) conducted a side-by-side comparison of wheat growth and yield in a hydroponic system and a zeoponic system in a controlled environment chamber.

Krutilina et al., (2000) indicated that zeolite improved biomass production and photosynthetic rate in maize and barley. Miller (2000) found that zeolite can work as soil amendment and has potential to influence the soil water content. Butorac et al., (2002) reported that the zeolites can be successfully used in cultivating different crops such as cereals, forage crops, vegetables, fruit crops and vine due to their exceptionally high ionexchange capacity. He et al., (2002) achieved increase in $\mathrm{N}$ use efficiency, $\mathrm{N}$ uptake, dry matter yield and reductions of losses by ammonia volatilization.

Rehakova et al., (2004) reported that plants grown in zeolite amended contaminated soil had higher growth parameters. Polat et al., (2004) reported that the mineral clinoptilolite (zeolite) enhanced the efficacy of applied fertilizers, ensuring better vegetative growth of crops and hence higher yields. Ayan et al., (2005) reported increased cation exchange ability, water retention and plant nutrients following zeolite application. Andronikashvili et al., (2008) suggested that in most of the researches, representing the early period, an increase in the yield of various agricultural plants under the influence of zeolites was caused by conditioning (structuring) the soil; improvement of its physico-chemical properties (creating favorable air and water regime close to the plant root system); 
increased cation-exchange capacity of soil; regular and rational plant nutrition.

Khodakovskaya et al., (2009) demonstrated that carbon nano tubes (CNTs) exposed seeds germinated up to two times faster than control seeds and the seedlings weighed more than twice as much as the untreated plants. Further, they demonstrated that CNTs could effectively penetrate seed coat, thereby influencing the seed germination and plant growth.

Srinivasan and Saraswathi (2010) reported that the seeds incubated in CNTs for two days possessed a moisture content of $57.6 \%$ compared to the value of $38.9 \%$ for the control. This is due to generation of new pores generated during penetration of seed coat by CNTs which aided better water permeation. Another possible cause reason could be the efficient gating of water channels by the CNTs in the seed coat. They also reported that, CNTs induces increased biomass, rapid germination and growth rates will in turn yield agriculture production in a short duration.

Ahmed et al., (2010) conducted experiment to investigate if the use of inorganic fertilizers together with zeolite will improve nitrogen $(\mathrm{N})$, phosphorus $(\mathrm{P})$ and potassium $(\mathrm{K})$ uptake and efficiency in maize (Zea mays) cultivation on Nyalau series. The result showed that the use of inorganic fertilizers mixed with zeolite remarkably increased $\mathrm{N}, \mathrm{P}$ and $\mathrm{K}$ uptake, and their use efficiency in leaves, stem and roots. The use of zeolite could be beneficial with respect to nutrient retention in soil and their use efficiency.

Overall, the literature served as a strong database to support that nano fertilizer and zeolite can effectively used in agriculture. Nanotechnology is an integral part of any nation's future. Research in nanotechnology can do a lot to benefit society through applications in agriculture and food systems (Sugunan and Dutta, 2004) Introduction of any new technology always has an ethical responsibility associated with it to be apprehensive to the unforeseen risks that may come along with the tremendous positive potential. Public awareness about the advantages and challenges of nanotechnology will lead to better acceptance of this emerging technology. Nanotechnology applications in agriculture and food systems is still at the nascent stage and a lot more applications can be expected in the years to come.

\section{Acknowledgement}

The authors would like to acknowledge her research guide Dr. K. S. Subramanian, Professor, Department of Nano Science and Technology for his valuable support and guidance throughout the research work.

\section{References}

Abdul-Kalam APJ (2007) Innovate to empower agriculture and convergence of technologies. Address and interaction with the students, faculty members and staff of the G.B. Pant University of Agriculture and Technology Pantnagar, Uttarakhand on 11 August 2007.

Agger JR (2003) Control of zeolite surface nucleation. Studies in Surface Science Catalysis 158: $35-42$.

Ahmed $\mathrm{OH}$, Sumalatha G, and NikMuhamad M (2010) Use of zeolite in maize (Zea mays) cultivation on nitrogen, potassium and phosphorus uptake and use efficiency. International J Physical Sci 5(15): 2393-2401.

Alexandre M, and Dubois P (2000) Polymer-layered silicate nanocomposites: preparation, properties and use of a new class of materials. Mater Sci Eng 28: 1-63.

Allen ER (1991) Supplying nitrogen, phosphorous, and potassium to plants through dissolution and ion exchange using a zeolitebase substrate: Ph.D (Agri.) Thesis, Texas A $\&$ M Univ, College Station. 
Allen ER, Hossner LR, Ming DW, and Henninger DL (1996) Release rates of phosphorus, ammonium and potassium in clinoptilolite phosphate rock systems. Soil Sci Soc Amer J 60: 1467-1472.

Amon M, Dobeic M, Sneath RW, Philips VR, Misselbrook TH, and Pain BF (1997) A farm-scale study on the use of clinoptilolite zeolite and deBodorase for reducing odor and ammonia emissions from broiler houses. Bioresource Tech 61: 229-237.

Andrews RD, and Shaw JW (2010) (http://www.zeoponix.com/new_page_5.htm)

Andronikashvili T, Urushadze T, Eprikashvili L, and Gamisonia M (2008) Towards the biological activity of the natural zeolite clinoptilolite-containing tuff. Bull. Georg. Natl. Acad. Sci 2: 65-68.

Ayan S (2001) Utilization of zeolite as plant growing media. East Mediterranean Forest Research Institute Journal 7: 97-111.

Ayan S (2002a) Using of zeolite mineral for seedling production and afforestration practices. Gazi Unv Faculty of Forestry Journal 1: 78-88.

Ayan S, Yahyaoglu Z, Gercek V, and Sahin A (2005) Utilization of zeolite as a substrate for containerised oriental spruce (Picea orientalisL.) seedlings propagation. International Symposium on Growing Media. INRA-INH-University d' Angers- France, 4$10 \mathrm{p}$.

Baerlocher $\mathrm{CH}$, Lynne B, and McCusker DH (2001) Olson Atlas of zeolite framework types, Sixth Edition 234-237.

Bagdasarov VR, Kazachenko AA, Rustambekov MK, Uspenskij BG, Kuznetsova VV, and Efremov EN (2004) Prolonged-activity nitrogen-zeolite fertilizer, Russia.

Bansiwal AK, Rayalu SS, Labhasetwar NK, Juwarkar AA, and Devotta S (2006) Surfactant modified zeolite as a slow release fertilizer for phosphorus. J Agric Food Chem 54: 4773 -4779.

Barbarick L, Lai TM, and Eberl DD (1990) Exchange fertilizer (phosphate rock plus ammonium-zeolite) effects on sorghumsudangrass. Soil Sci Soc Am J. 54: 911-6.

Bardakci B, and Bahceli S (2010) FTIR study of modification of transition metals on zeolite. Indian J Pure and Appl Physics 48: 615-620.
Baruah S, Warad HC, Chindaduang A, Tumcharern G, and Dutta J (2008) Studies on chitosan stabilised Zns: $\mathrm{Mn}_{2}{ }^{+}$Nanoparticles, J Bio Nano Sc in press.

Bhardwaj D, and Tomar R (2011) Use of surface modified inorganic nano materials as slow release nitrogen fertilizer.Sustainable Agricultural Development Part 3, 171-184p.

Bhattacharya SS, Debkanta GN, Mandal, Chattopadhyay, and Majumdar K (2004) Effect of Balanced Fertilization on Pulse Crop Production in Red and Lateritic Soils. Better Crops 88(4): 52-57.

Bouguerra W, Mnif A, Hamrouni B, and Dhahbi M (2008) Boron removal by adsorption onto activated alumina and by reverse osmosis. Desalination 223: 31.

Broos K, Warne J, Heemsbergen DA, Stevens D, Barnes MB, Correll RL, and Mclaughlin MJ (2007) Soil factors controlling the toxicity of copper and zinc to microbial processes in Australian Soils. Environ Toxi Chem 26 (4): 583-590.

Bruhwiler L (2005) Controlling size and morphology of zeolite. Materials Syntheses 31: 9-19.

Bryjak M, Wolska J, and Kabay N (2008) Removal of boron from seawater by adsorptionmembrane hybrid process: Implementation and challenges. Desalination 223: 57.

Buentello S, Persad DL, Court EB, Martin DK, Daar AS, and Peter A (2005) Nanotech and the developing world. Pl Med 2: 97.

Burriesci IN, Valente S, Ottana R, Cimino G, and Vezipelli C (1984) Utilization of zeolites in spinach growing. Zeolites 4: 58.

Butorac A, Filipan T, Basic ZF, Butorac J, Mesic M, and Kisic I (2002) Crop response to the application of special natural amendments based on zeolite tuff. Rostlinna Vyroba. (In Czech) 48: 118-124.

Cengeloglu Y, Tor A, Arslan G, Ersoz M, and Gezgin S (2007) Removal of boron from aqueous solution by using neutralized red mud. J Hazard Mater 142: 412.

Chau CF, Wu SH, and Yen GC (2007) The development of regulations for food nanotechnology. Trends in Food Science and Technology. 18: 269-280.

Chuprova VV, Ulyanova OA, and Kulebakin VG (2004) The effect of bark-zeolite fertilizers on mobile humus substances of chernozem and 
on biological productivity of Corn. Poster presented Euro Soil,Freiburg, Germany. 4 $12 p$.

Dakovic A, Tomasevic M, Rottinghaus EG, Matijasevic S, and Sekulic Z (2007) Fumonisin B1 adsorption to octadecyldimetylbenzyl ammonium-modified clinoptilolite-rich zeolitic tuff. Microporous and Mesoporous Materials 105: 285-290.

Das S, Gates AJ, Abd HA, Rose GS, Picconatto CA, and Ellenbogen JC (2007) Designs for ultra-tiny, special-Purpose Nano electronic Circuits. IEEE Transactions on Circuits and Systems 154: 2528-2540.

DeRosa MC, Monreal C, Schnitzer M, Walshand R, and Sultan Y (2010) Nanotechnology in fertilizers. Nature Nanotechnol 5: 540-547.

Desborough GA (1996) Nitrogen-loading capacities of some clinoptilolite-rich rocks: U.S. Geological Survey Open File Report, 96-661: 17.

Dwairi JM (1998) Renewable, controlled and environmentally safe phosphorous released in soil mixtures of $\mathrm{NH}_{4}^{+}$-phillipsite tuff and phosphate rock. Environ. Geology 34: 293296.

Eberl DD (2008) Controlled release fertilisers using zeolites. USGS science for changing world. Tech. Transfer p: 1-3.

Fansuri H, Prichard D, and Dong-Ke-Zhang (2008) Manufacture of zeolites from flyash for fertilizer applications. Ph.D (Agri.) Thesis. Centre for fuels and energy, Curtain University of Technology, Australia.

Ferrari M (2005) "Cancer nanotechnology: opportunities and challenges". Nat Rev Cancer 5(3): 161-171.

Ferreira OP, Gomes de Moraes S, Duran N, Cornejo L, and Alve OL (2006) Evaluation of boron removal from water by hydrotalcitelike compounds. Chemosphere 62-80.

Flanigen M, and Mumpton FA (1981) Commercial properties of natural zeolites. In: F.A. Mumpton (ed.). Mineralogy and geology of natural zeolites, Reviews in Mineralogy. Miner Soc Amer 4: 165-175.

Gruener JE, Ming DW, Henderson KE, and Galindo-Jr C (2003) Common ion effects in zeoponic substrates: wheat plant growth experiment. Microporous and Mesoporous Materials 61: 223-230.
Guo X, Zenga L, Li X, and Spark H (2008) Ammonium and potassium removal for anerobically digested waste wáter using natural clinoptilolite followed by membrane pretreatment. J Hazard Mater 151: 125-133.

Gupta G, Borowiec J, and Okoh J (1997) Toxicity identification of poultry litter aqueous leachate. Poultry Sci 76: 1364-1367.

He ZL, Calvert DV, Alva AK, Li YC, and Banks DJ (2002) Clinoptilolite zeolite and cellulose amendments to reduce ammonia volatilization in a calcareous sandy soil. Plant Soil 247: 253-260.

Hershey DR, Paul JL, and Carlson RM (1980) Evaluation of potassium-enriched clinoptilolite as a potassium source for potting media. Hort Sci 15: 87-89.

Hillie $T$ (2007) Nano computers and swarm intelligence. London: ISTE. p26. ISBN 1847040020

Huang ZT, and Petrovic AM (1994) Clinoptilolite zeolite influence on nitrate leaching and nitrogen use efficiency in simulated sand based golf greens. J Environ Qual 23: 11901194.

Jinghua G (2004) Synchrotron radiation, soft Xray spectroscopy and nano-materials. J Nanotech 1(1-2): 193-225.

Junrungreang S, Limtong P, Wattanaprapat $K$, and Patsarayeangyong T (2002) Effect of zeolite and chemical fertilizer on the change of physical and chemical properties on Lat Ya soil series for sugar cane. $17^{\text {th }}$ WCSS, Thailand.

Kavak D (2009) Removal of boron from aqueous solutions by batch adsorption on calcinedalunite using experimental design. $\mathbf{J}$ Hazard Mater 163: 308.

Khodakovskaya M, Dervishi E, Mahmood M, Xu Y, Li Z, Watanabe F, and Bris AS (2009) Carbon nanotubes are able to penetrate plant seed coat and dramatically affect seed germination and plant growth. ACS Nano 3: 3221-3227.

Kithome, M, Paul J, and Lavkulich W (1998) Kinetics of ammonium sbsorption and desorption by the natural zeolite clinoptilolite. Soil Sci Soc Amer J 62: 622-623.

Kose TE, and Ozturk N (2008) Boron removal from aqueous solutions by ion-exchange resin: Column sorption-elution studies. J 
Hazard Mater 152: 744.

Krutilina VS, Polyanskaya SM, Goncharova NA, and Letchamo W (2000) Effects of zeolite and phosphogypsum on growth, photosynthesis and uptake of $\mathrm{Sr}, \mathrm{Ca}$ and $\mathrm{Cd}$ by barley and corn seedlings. PartAToxic/Hazardous-Substances and Environmental Engineering. J Environ Sci Health 35(1): 15-29.

Kuzma J, and Verhage P (2006) Nanotechnology in Agriculture and Food Production: Anticipated Applications. Project on Emerging Nanotechnologies and the Consortium on Law, Values and Health and Life Sciences. Centre for Science, Technology and Public Policy (CSTPP).

Latifah $\mathrm{O}$, Ahmed $\mathrm{OH}$, and NikMuhamad AM (2011) Reducing ammonia loss from urea and improving soil exchangeable ammonium and available nitrate in non waterlogged soils through mixing zeolite and sago (Metroxylonsagu) waste water. International J Physical Sci 6(4): 866-870.

Lefcourt AM, and Meisinger JJ (2001) Effect of adding alum or zeolite to diary slurry on ammonia volatilization and chemical composition. J Dairy Sci 84: 1814-1821.

Li JX, Wee CD, and Sohn BK (2010) Growth response of hot pepper applicated with ammonium $\left(\mathrm{NH}_{4}^{+}\right)$and Potassium $\left(\mathrm{K}^{+}\right)$Loaded Zeolite. Korean J. Soil Sci. Fert. 43(5): 619-625.

Li Z (2003). Use of surfactant-modified zeolite as fertilizer carriers to control nitrate release. Microporous and Mesoporous Materials 63: 181-188.

Li Z, and Zhang Y (2010) Use of surfactantmodified zeolite to carry and slowly release sulfate. Desalin water treat. 21:73-78.

Lin D, and Xing B (2008). Root uptake and Phytotosicity of $\mathrm{ZnO}$ nanoparticles. Environ Sci Tech 42: 5580-5585.

Liu M, Liang R, Liu F, and Niu A (2006). Synthesis of a slow release and superabsorbent nitrogen fertilizer and its properties. Polym Adv Tech 17: 430-438.

Lo PK, Karam P, and Sleiman HF (2010) Loading and selective release of cargo in DNA nano tubes with longitudinal variation. Nature chemistry, 14 March.

Malakouti MJ (2008) The effect of micronutrients in ensuring efficient use of macronutrients. Turk J Agric 32: 215-220.

Malhi SS, Haderlin LK, Pauly DG, and Johnson AM (2002) Improving fertiliser use efficiency. Better Crops 86: 22-25.

Markovich A, Takac A, Illin Z, Ito T, and Tognoni F (1995) Enriched zeolites as substrate component in the production of paper and tomato seedling. Acta Horticulturae 396: 321-328.

Maysinger D (2007) Nanoparticles and cells: good companions and doomed partnerships. Org.Biomol.Chem. 5(15): 2335-2342.

Mazur GA, Medvid GK, and Gvigora IT (1986) Use of natural zeolite to increase the fertilizer of coarse soils. Soviet Soil Sci 16(4): 105111.

Mcgilloway R, Weaver R, Ming D, and Gruener JE (2003) Nitrification in a zeoponic substrate. Plant Soil 256: 371-378.

Melendi G, Fernandez-Pacheo P, Coronado R, Corredor MJ, Testillano E, Risueno PS, and Marquina MC (2008) Nanoparticles as smart treatment delivery systems in plants: assessment of different techniques of microscopy for their visualization in plant tissues. Ann Bot 101: 187-195.

Miller GL (2000) Physiological response of Bermuda grass grown in soil amendments during drought stress. Hort Sci 35(2): 213216.

Ming DW, and Allen ER (2001) Use of natural zeolites in agronomy, Horticulture, and environmental soil remediation. In Natural Zeolites: Occurrence, Properties, Applications (eds Bish, D. L. and Ming, D. W.), The Mineralogical Society of America, Washington, DC 45: 619-654.

Ming DW, and Mumpton FA (1989). Zeolites in soils. In 1B. Dixon and S.B. Weed, Ed., Minerals in soil environments. Soil Science Society of America, Madison, Wisconsin 873-911.

Moraru C I, Panchapakesan C P, Huang Q R, Takhistov P, Sean L, and Kokini J L (2003) Nanotechnology - A new frontier in food science. Food Technology 57 (12): 24-29.

Mumpton FA (1981) Utilization of natural zeolites. Mineralogy and geology of natural zeolites, In: F.A. Mumpton (ed.). Mineralogy and geology of natural zeolites, Reviews in 
Mineralogy. Miner Soc Amer 4: 177-204.

Mumpton FA (1999) La roca: Uses of natural zeolites in agriculture and industry. Proceedings of the National Academy of Sciences Online 96: 3463-3470.

Ozturk N, Kavak D, and Kose T.E (2008) Boron removal from aqueous solution by reverse osmosis. Desalination 223: 1.

Pandey AC, Sanjay SS, and Yadav RS (2010) Application of $\mathrm{ZnO}$ nanoparticles in influencing the growth rate of Cicer arietinum. Journal of Experimental Nanoscience 5 (6): 488-497.

Peppas NA (2004). "Intelligent therapeutics: Biomimetic systems and nanotechnology in drug delivery". Advanced Drug Delivery Reviews 56 (11): 1529-153.

Perrin TS, Boettinger JL, Drost DT, and Noron JM (1998b) Decreasing nitrogen leaching from sandy soil with ammonium-loaded clinoptilolite. J Environ Qual 27: 656-663.

Perrin TS, Drost DT, Boettinger JL, and Noron JM (1998a) Ammonium-loaded clinoptilolite: A slow-release nitrogen fertilizer for sweet corn. J Plant Nutr 21: 515-530.

Perrin TS, Dros DT, Boettinger JL, and Norton JM (1998) Ammonium-loaded clinoptilolite: A slow-release nitrogen fertilizer for sweet corn. J Plant Nutri 21: 515-530.

Pessarakli M (1994) Handbook of Plant and Crop Stress. Marcel Dekker, Inc, New York pp: 1067-1084.

Pickering HW, Menzies NW, and Hunter MN (2002) Zeolite/rock phosphate-A novel slow release phosphorus fertilizer for potted plant production. Sci Hort 94: 333-343.

Polat E, Karaca M, Demir H, and Naci-Onus A (2004) Use of natural zeolite (clinoptilolite) in agriculture. J Fruit Ornament Plant Res 12: 183-189.

Polat H, Vengosh A, Pankratov I, and Polat M (2004) A new methodology for removal of boron from water by coal and fly ash. Desalination 164: 173.

Qiang X, Fu-dao Z, Yu-jun W, Jian-feng Z, and Shu-qing $Z$ (2008) Effects of slow/controlled release fertilizers felted and coated by nanomaterials on crop yield and quality. 5-10.

Ramesh K, Biswas AK, Soma Sundaram J, and Subba Rao A (2010) Nanoporous zeolites in farming: Current status and issues ahead.
Current Sci 99 (6): 25.

Rana RK, and Viswanathan B (1998) Mo incorporation in MCM-41 type zeolite. Catalysis Letters. 52(1):25-29.

Rehakova M, Cuvanova S, Dzivak M, Rimar J, and Gavalova Z (2004) Agricultural and agrochemical uses of natural zeolite of the clinoptilolite type. Current Opinion in Solid State and Materials Science 8: 397-404.

Remya Nair, Saino Hanna, Varghese Baiju Nair G, Maekawa T, Yoshida Y, and Sakthi Kumar D (2010) Nanoparticulate material delivery to plants. Plant Sci179(3): 154-163.

Rezaei M, and Movahedinaeini SAR (2009) Effects of ammonium and Iranian natural zeolite on potassium adsorption and desorption kinetics in the loess soil. International J Soil Sci 4: 1-19.

Roco (2003) Broader societal issues of nanotechnology. J Nanoparticle Res 5(3-4): 181-189.

Sabarudin A, Oshita K, Oshima M, and Motomizu S (2005) Synthesis of cross-linked chitosan possessing N-methyl-d-glucamine moiety (CCTS-NMDG) for adsorption/ concentration of boron in water samples and its accurate measurement by ICP-MS and ICP-AES. Talanta 66: 136.

Sahoo SK, and Labhasetwar V (2003) "Nanotech Approaches to Drug Delivery and Imaging". Drug Discov Today 8 (24): 1112-1120.

Schmidt R, and Szakal P (2007) The application of copper and zinc containing ion-exchanged synthesised zeolite in agricultural plant growing. Nova Biotechnologica. 57-62.

Schneider A (2010) “Amid Nanotech's Dazzling promise, Health Risks Grow". (http:/www.aolnews.com/nanotech/article/am idnantechs-dazzling-promise-health risksgrow/19401235). March, 24.

Science Policy Council, Environ. Prot. Agency, Nanotechnology White Paper (2007).

Scott, NR (2007) Nanoscience in veterinary medicine. Veterinary research communications. 31 (Suppl.): 139-144.

Sharmila Rahale (2011) Nutrient release pattern of nanofertilizer formulation. Ph.D (Agri.) Thesis. Tamilnadu Agricultural University, Coimbatore.

Sheta AS, Falatah AM, Al-Sewailem MS, Khaled EM, and Sallam ASH (2003) Sorption 
characteristics of zinc and iron by natural zeolite and bentonite. Microporous and Mesoporous Mat 61: 127-136.

Shi X, Wan S, Meshinchi S, Van Antwerp ME, Bi X, Lee I, and Baker JR (2007) Dendrimer entrapped gold nanoparticles as a platform for cancer cell targeting and imaging. Small, 3: 1245-1252.

Sinha RS, and Bousmina M (2005) Biodegradable polymers and their layered silicate nanocomposites: in greening the 21st century materials world. Prog Mater Sci 50: 9621079.

Sinha RS, and Okamoto M (2003) Polymer/layered silicate nanocomposites: A review from preparation to processing. Prog Polym Sci 28: 1539-1641.

Song JQ, and Fujiyama H (1996) Differences in response of rice and tomato subjected to sodium salinization to the addition of calcium. Soil Sci Plant Nutri 42: 503-510.

Srinivasan C, and Saraswathi R (2010) Nanoagriculture - carbon nanotubes enhance tomato seed germination and plant growth. Current Sci 99: 274-275.

Steinberg SL, Ming DW, Henderson KE, Carrier C, Gruener JE, Barta DJ, and Henninger DL (2000) Wheat response to differences in water and nutritional status between zeoponic and hydroponic growth systems. Agron J 92: 353-360.

Subramanian KS, and S Rahale (2009) Synthesis of nanofertiliser formulations for balanced nutrition. Proceedings of the Indian society of soil science-platinum Jubilee celebration. IARI, Campus, New Delhi. 85p.

Subramanian KS, Paulraj C, and Natarajan S (2008) Nanotechnological approaches in Nutrient Management. In: Nanotechnology
Applications in Agriculture 37-42.

Sugunan A, and Dutta J (2004) IEEE International Conference on Semiconductor Electronics A6- A11.

Supapron J, Pitayakon L, and Wattanaprapat (2007). Effect of zeolite and Chemical fertilizer on the change of physical and chemical properties on LatYa soil series for sugarcane. $17^{\text {th }}$ WCSS, Thailand.

Supapron J, Pitayakon L, Kamalapa W, and Touchamon P (2002) Effect of zeolite and chemical fertilizer on the change of physical and chemical properties on LatYa soil series for sugar cane. $17^{\text {th }}$ WCSS, Thailand.

Treacy MJ, and Higgins JB (2001) Collection of simulated XRD powder patterns for zeolites, $4^{\text {th }}$ edition. Elsevier, Amsterdam.

Turek M, Dydo P, Trojanowska J, and Campen A (2007) Adsorption/co-precipitation-reverse osmosis system for boron removal. Desalination 205, 192.

Valente S, Burriesci N, Cavallaro S, Galvagno S, and Zipelli C (1986) Utilization of zeolite as soil conditioner in tomato growing. Zeolites 2(4): 271-274.

Zhang F, Wang R, Xiao Q, Wang Y, and Zhang J (2006) Effects of slow/controlled - release fertilizer cemented and coated by nanomaterials on plants. Nanoscience 11: 8-26.

Zhou JM, and Huang PM (2007) Kinetics of potassium release from illite as influenced by different phosphates. Geoderma 138: 221228.

Zhou, Bing, Hermans S, and Gabor A (2004) Nanotechnology in catalysis. ISBN: 978-0306-555.

\section{How to cite this article:}

Selva Preetha, P. and Balakrishnan, N. 2017. A Review of Nano Fertilizers and Their Use and Functions in Soil. Int.J.Curr.Microbiol.App.Sci. 6(12): 3117-3133. doi: https://doi.org/10.20546/ijcmas.2017.612.364 